\title{
Gabriel Richet (1916-2014), Founding Editor of Nephron
}

We announce, with deep sorrow, the death of Professor Gabriel Richet.

On a shelf in my office is a small pile of scientific reprints, each bearing a small hand-written inscription and interleaved with thoughts and suggestions on the notepaper of Professor Gabriel Richet. He sent these to me knowing that I would enjoy reading his views on 'An unrecognized renal physiologist: Fredrich Wohler' or 'La naissance de l'urémie', 'Osmotic diuresis before Homer W. Smith: a winding path to renal physiology' or 'The osmotic pressure of the urine - from Dutrochet to Koranyi, a trans-European interdisciplinary epic', and many more like those. His only urging was that the novelty of the concepts be understood, and that credit be assigned to those who initiated the ideas, regardless of how well they had been recognized by others and regardless from where they hailed.

This was Richet - charming, polite, regal and yet challenging, honest and often indignant. He once said to me with a smile on his face, 'you are a stupid man!' He was right - I had made a foolish remark to the wrong person. I recanted. I enjoyed receiving such a direct rejoinder from one of the acknowledged giants in the field of nephrology.

Gabriel Richet came from a lineage of distinguished men of medicine, the fourth in a family of professors at the Faculté de Médecine in Paris. During the Second World War he joined the resistance with other members of his family who were deported or jailed. He himself was held in captivity. After the liberation of France, he enrolled in the army and participated in the ongoing fighting as a doctor, for which he received three citations, ul-

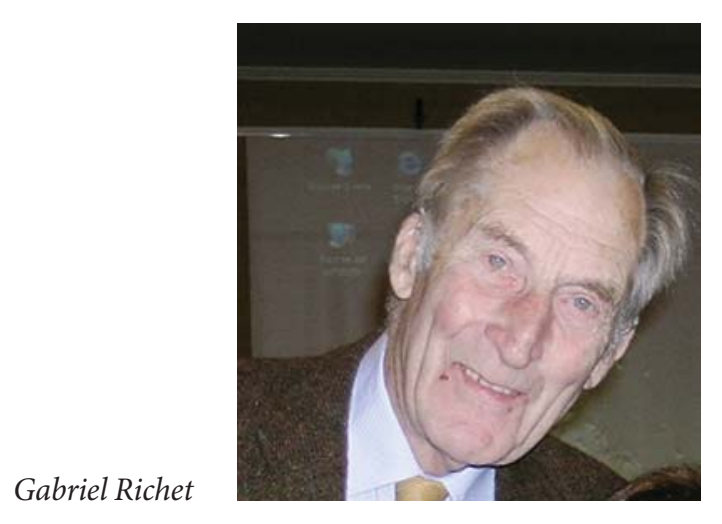

timately being decorated with the Chevalier de la Légion d'Honneur by General de Gaulle in 1945.

Thereafter, Gabriel Richet fell under the wing of Professor Jean Hamburger at the Necker Hospital in Paris. Together they built one of the leading nephrology centers in the world, being at the forefront of the treatment of acute and chronic kidney failure, dialysis and renal transplantation. Throughout his career, he sought to understand the pathophysiological basis of the diseases he was treating and to apply such knowledge to devising appropriate therapeutic approaches. This eventually led to an intensive care approach in his unit to the management of fluid, electrolyte and metabolic disorders.

1961 was an important year for Richet. This is when he moved to Tenon Hospital, where he started to build an impressive team of clinical nephrologists and scientists. It was also in 1961 that the first notion of creating an international nephrology journal was proposed. The Execu-

\section{KARGER}

E-Mail karger@karger.com

www.karger.com/nec
(C) 2014 S. Karger AG, Basel

$1660-2110 / 14 / 1284-0414 \$ 39.50 / 0$ 
tive Committee of the International Society of Nephrology (ISN), of which Richet was a founding member, approved the idea of an international journal to be called 'Nephrologia'. Richet, then Secretary General to the first International Congress of Nephrology in Geneva and Evian, was to be its first Editor-in-Chief. It took until 1964 with various contortions for 'Nephron' to be selected as the name of the new journal, and this was established with Gabriel Richet in Paris and George Schreiner in Washington DC as its first Editors-in-Chief. The publisher was Karger of Basel, Switzerland. Under their editorship the journal served as the instrument of the ISN until 1971, when the ISN established a new journal under its ownership.

Although Gabriel Richet himself was a masterful clinician and astute observer of clinical phenomena, he was also understanding of the fact that clinical science can only advance on the solid shoulders of good basic science. In this regard, the colleagues that he drew near to him were those who shared this appreciation, and together they built a research unit at Tenon which was ultimately supported both by the public hospital system and INSERM, the French institution supporting biomedical research. He was proud of his disciples; he allowed them the freedom to go their own ways and would often whisper words of admiration when I happened to sit next to him at meetings. He was never shy about indicating who he thought was going to achieve greatness and how important it was to support them. His protégés moved into academic leadership positions in French nephrology and his trainees populated renal divisions around the world.

Gabriel Richet's honors included being elected President of the ISN (1981-1984), receipt of the Jean Hamburger prize of the ISN and his appointment as Grand Officer of the French Legion of Honour.

I would like to believe that added to this list should also be the small house which Richet built, i.e. Nephron, which celebrates its 50th anniversary in 2014. When the first issue of 2014 emerged from the press, I sent it to its founding editor, who was the last surviving founding father of the ISN, to show him the durability of what he had created half a century earlier. I do hope that he put it on his shelf and looked at it with the same pride as I do upon the publications and letters which he sent me over the years. We will all miss this great man.

Leon G. Fine, Editor-in-Chief Nephron Journals, 2004-2014 